\title{
Analysis of Corporate Governance Index Using ASEAN Balanced Score Card and Firm Performance
}

\author{
Thi Thanh Binh Dao* $\quad$ Pham Hai Chi Nguyen \\ Hanoi University, Faculty of Management and Tourism, Km 9 Nguyen Trai, Thanh Xuan District, Hanoi
}

\begin{abstract}
Governance plays a crucial role in most activities of socio-economic life. For any organizations, units, businesses or higher, a country, a community, the role of governance becomes more important than ever. For businesses, with globalization taking place and market becoming more competitive than ever, good Corporate Governance is now considered as a factor of success. Good corporate governance will help the company improve its ability to access to various sources of capital and operate more efficiently. However, in Vietnam particularly, Corporate Governance system still need to enhance and improve. Therefore, with the aim of surveying the current situation of Corporate Governance practices in Vietnam and giving the analysis of its impacts on businesses' performance, this research is conducted from a sample of 60 listed-companies in both Construction and Food \& Beverage industry for the time 2015, 2017 and 2018. By using the tool of ASEAN balanced scorecard to evaluate Vietnam Corporate Governance practices on 05 aspects: Rights of shareholders, Equitable treatment of shareholders, Roles of stakeholders, Disclosure and transparency and Board duties and responsibilities, the paper came to the low results of companies' Corporate Governance practices in Vietnam. Based on this method, different relationships were found, one of which is the positive relationship between Corporate Governance Index and Tobin's Q.
\end{abstract}

Keywords: Asean Score Card, Corporate Governance Index, Performance

DOI: $10.7176 /$ RJFA/11-6-02

Publication date:March $31^{\text {st }} 2020$

\section{Introduction}

Since people began to form groups to accomplish goals that could not achieve individually, governance has become essential to ensure coordination between different individuals. Alongside with the fast growth of businesses in both amount and scale today, particularly within the listed firm in Vietnam, Corporate Governance - a tool to help separate proprietorship and management, is increasingly drawing attention of numerous organizations and lawmakers on businesses.

Generally, governance is the process of laying the foundations of basic operational principles for an enterprise. The topic of Corporate Governance is conceived from the matter of partition between management and shareholders of companies. Whether a company is a public company or a private one, Corporate Governance is always meant to protect stakeholders' rights and people related. In the case of public companies, there are a lot of small shareholders whose voices seem to be restricted, thus there should exist a transparent system to protect their rights. Moreover, as investors depend on public sources of information to have an understanding of the company, they need to make sure of the quality, accuracy and clarity of financial information. Thereby, transparency in Corporate Governance system is necessarily required. This transparency will increase investors' confidence in making investment decisions. As a result, businesses can attract more capital, particularly from foreign investors. Overall, Corporate Governance give companies directions to create value for both shareholders and society in a competitive market.

In Vietnam particularly, the Corporate Governance is now taken more seriously by businesses but it is yet in a strong position. In ASEAN disclosure index 2018 conducted by FTI Consulting Group on top 180 listed companies ranking on disclosure quality, Vietnam ranked last in all three categories: composite disclosure, board quality and risk disclosure. Meanwhile on State enterprises, according to the Ministry of Planning and Investment, in 2017, only 265/622 enterprises (accounting for $42.6 \%$ of the State enterprises) sent reports to the Ministry to publish information on Business Portal and in 2016, this rate was only $38.9 \%$ (D, A 2018).

With globalization taking place and market becoming more competitive than ever, the importance of good Corporate Governance is seriously considered and its impact on firm's performance are unavoidable and undeniable. It might be the reason that many studies have been done to analyze this relationship.

Hence, this paper will contribute to the topic of the connection between Corporate Governance Index and firm performance. Particularly, with the use of ASEAN scorecard method, the score for each category in Corporate Governance will be calculated based on disclosed information of companies in public. After that, the relationship between Corporate Governance score and firm performance is tested and discussed. In order to conduct the paper, a sample of 60 non-financial companies in Food \& Beverage \& Construction industry listed on Ho Chi Minh Stock Exchange (HOSE) and Hanoi Stock Exchange (HNX) for three years (2015, 2017 and 2018) is chosen. Year 2016 is omitted, as we want to observe the changing progress more clearly.

In details, this paper covers the following four purposes: Providing basic information about Vietnam 
Corporate Governance, Corporate Governance Index as well as the use of ASEAN scorecard; Identifying the score for each categories in Corporate Governance mechanism of 60 listed companies in Vietnam for three years (2015, 2017 and 2018) by using ASEAN scorecard; Discussing the relationship between Corporate Governance score calculated based on ASEAN scorecard and firm performance measured through market-based valuation and accounting-based valuation and Provide discussing the reasons for the Vietnam Corporate Governance scores and recommendation for improvement.

This paper is divided into 5 sessions. Session 1 introduces the topic of the paper. Next, session 2 provides information on the literature review of theoretical literature and empirical studies that have been done in previous work. Followed by is session 3, which includes the methodology of the research, and session 4 is given for results. Finally yet importantly, session 5 concludes on the discussion of findings of the paper as well as some limitation when conducting the research and recommendation for improving.

\section{Literature Review}

2.1 Corporate Governance in Asia

According to the book Corporate Governance in Development (2003), which was published by OECD Development Centre, the matter of Corporate Governance had never been considered adequately in developing countries. It remained practically imperceptible in those nations until the East Asia financial crisis of 1997-1998. Mentioned in the study of Corporate Governance in Southeast Asia by Philippines Institution for Development Studies, the downturn of economy revealed latent problems (e.g. corruption), exacerbated others (e.g. poor resource management) and gave rise to new ones (e.g. political instability) (Eduardo \& Magdalena 2009). Also in major Southeast Asia countries such as Malaysia, Philippines, Indonesia and Thailand, the factors of poor investment structure, weak legal and accounting system, faulty financial practices, questionable political interventions had been described as substantial contributors to the decline of economic during the crisis stage (Ho 2005). Such pressure has provoked the desire of implementing new policies to strengthen the condition of Corporate Governance, recover economy and prevent external shocks from transforming into major crisis. Those policies included transparency, institutional accountability and fiscal prudence (Ho 2005). Moreover, the corporate restructuring was not restricted to these countries affected only but also adopted by those nations that were not influenced by the crisis, such as China, Taiwan and Singapore since they believed that prevention is better than cure. Vietnam is not an exception in this turning point of reforming.

However, not until 2005 when Vietnam Enterprise Law was published that it led to a significant improvement in Corporate Governance in general and in shareholding companies in particular (Nguyen 2008). In term of legal status, the advent of the stock market and the issuance of Decision 12/2007/QD-BTC on Corporate Governance Regulations applied to companies listed on the Stock Exchange have shown the initial attention of Vietnam to listed companies' Corporate Governance. Since then, Vietnam has continuously improved the legal framework on Corporate Governance by issuing Circular 52/2012/TT-BTC about information disclosure on the stock market, Circular No.121/2012/TT-BTC on Corporate Governance Regulations applicable to public companies or Decree No.108/2013/ND-CP about sanctions executed for administrative violations in the field of securities and securities market. The introduction of these documents has helped improve Corporate Governance compliance and enforcement of public companies in Vietnam. Moreover, these actions are also seen as the determination of Vietnam in improving the legal framework for Corporate Governance operations with the aim to shorten the distance with the world.

In 2008, the World Bank made a comparative study of Corporate Governance in different countries such as Thailand, Vietnam, Indonesia and Malaysia, for the periods 2003-2006, the author summarized and made the comparison between four countries based on scores observed in each category. Generally, there were total of 22 categories and the maximum score attainable was 110. As a result, Vietnam achieved lowest overall score (50.9) and ranked below Malaysia, Thailand, and Indonesia whose scores were 77.3, 72.7 and 60 respectively. In details, it is seen that over 22 categories, Vietnam ranked at the last position in 19 categories, which included Basic shareholder rights, shareholders' annual general meeting rights, equal treatment of shareholders, prohibition of insider trading, disclosure of interests, etc., to name a few. Especially with such categories like Objective judgment exercise, The board responsibility, Law compliance, Fair treatment to shareholders, Fair and timely dissemination, Disclosure standards, Disclosure of Interests, Insider trading prohibition, Equal treatment of shareholders, it was hardly observed from Vietnamese companies' Corporate Governance mechanism. The outcomes evidently shown a fact that the corporate governance system in Vietnam was still lacking and unclear compared to other countries in region.

A report published by ASEAN Capital Markets Forum also indicated the inferior status of Vietnam Corporate Governance compared to another five ASEAN country members including Indonesia, Malaysia, Philippines, Singapore and Thailand. Although the point for Vietnam Corporate Governance practices got better and better during the period 2011-2015 (from 28.4 points in 2011 to 36.75 points in 2015), Vietnamese listed companies still had the lowest average management score among the six ASEAN member countries surveyed, reflecting the 
limited Corporate Governance activities in Vietnam's listed companies.

\subsection{Corporate Governance and firm performance in Asia}

The situation of globalization worldwide has exacerbated competition within the country and even across national boundaries, followed by a controversy around the world that whether better-governed firms outperform the others (Akshita \& Shernaz 2018). This is undoubtedly an urge for researchers to start the discovery into the influences of Corporate Governance system on corporations' performance.

In the research published by Shafie, Kamilah \& Khaw (2016) took into consideration the relationship between Corporate Governance Practices and Firm Performance with the evidence from Top 100 Public Listed Companies in Malaysia. The researchers used Board size and Board Independence as two indicators to test the hypothesized relationship between the Corporate Governance and firm performance. Wen-Yen \& Pong Pitch presented another paper studying about The Corporate Governance on the Efficiency Performance of Thai non-life insurance industry in 2010. The research discovered the negative impact of audit committee size, diligence, voting rights, board tenure, board age and board ownership on firm performance whose measures were based on firm's technical, allocative, cost, and revenue efficiency.

In Vietnam, the structure of Corporate Governance has just been in a beginning period of development. However, there are gradually lot of researchers paying attention to this matter and start to conduct analysis exploiting the better Firm Performance by developing Corporate Governance. One of some outstanding papers is "The impact of Corporate Governance on firm performance: Empirical Study in Vietnam" conducted by Vo \& Nguyen (2014). By taking the dataset of 177 listed companies in Vietnam for the time period from 2008 to 2012 , the authors found some noticeable results which were the positive correlation between duality role of the CEO and firm performance, the opposite effects of board independence on firm performance and the structural change between the organizational ownership and firm performance.

With the approach of taking a sample of 30 listed companies from VN30 Index, Dao (2018) analyzed the dataset and got the findings of positive correlation between number of Director Board, independent CEO and Major Shareholders and performance of Vietnamese non-manufacturing firms. Also conducted by Dao \& Hoang (2012) but focused on banking industry only, the research of Corporate Governance and Performance in Vietnamese Commercial Banks concluded the huge influence of the Director Board member's number and ratio of capital adequacy on the bank's performance. The findings can be utilized usefully and be great assistance in helping organizations minimize business risks. Pham (2016) can examine the impact of Corporate Governance on firm performance measured as ROA and Tobin's Q. However, in case of Tobin's Q, there was no significant correlation between ownership of managers and firm performance.

Manmeet and Madhu (2018) constructed a CGI to examine the good governance practices of Indian banks and to see whether the banks had great performance accordingly. The outcome demonstrated that CGI is significantly and positively in correlation with banks' financial performance measures, which are, return on assets, economic value added and Tobin's Q. Also conducting the research in India context but on business firms, Akshita and Shernaz (2018) used essential parameters of Corporate Governance such as ownership structure and board structure to build CGI to discover the relationship between Corporate Governance Index and firm performance. As a result, the firm performance metrics (Returns on assets, earning per share and return on net worth) are proved to have significant positive relationship with CGI. With these empirical evidence, firms may have good incentives to deliberately improve their Corporate Governance as it helps to enhance their performance. Additionally, the investors would likewise have positive view on business firms keeping up high governance standards, therefore lessening possible funding costs.

Another study needed to mention is the research conducted in 2007 by Langfen et al. By taking the sample of firms listed in Taiwan, they constructed a CGI based on four different dimensions of a firm's Corporate Governance structure: CEO duality, size of the board of directors, managements' holdings and block shareholders' holding to clarify the connection between ownership/leadership structures and stock returns of these firms.

In Vietnam, to my best knowledge, there have not been many researchers studying the association between the firm performance and CGI. In 2018, Dao \& Nguyen published their study of "The impact of Corporate Governance Index on the performance of listed companies VN30 Index". The index questions are based on Thailand Corporate Governance Report (2012) and OECD principals. The result shows that Corporate Governance Index has significant effect on the firm performance of company, which is measured by ROA.

There have not had many researches that using ASEAN scorecard to measure the standards of listed companies' corporate governance in Vietnam or the study about relationship between ASEAN governance scorecard and firm performance. The only source that using the ASEAN scorecard to giving an overview of Vietnamese Corporate Governance is the ASEAN Corporate Governance Scorecard Country Reports and Assessments done by the cooperation of ASEAN Markets Forum \& The ASEAN Development Bank from 2012 to 2015. Besides the assessment of publicly listed companies in Indonesia, Malaysia, Philippines, Singapore and Thailand, Vietnam is also included in the group for evaluation. By giving score to 2 levels of scoring, which covers 
areas of OECD principals (rights of shareholders, equitable treatments of shareholders, role of stakeholders, disclosure and transparency and responsibility of the board), among 50 Vietnamese listed companies participating in the evaluation Petro Viet Nam Fertilizer and Chemicals, Ho Chi Minh City Securities and Viet Nam Dairy Products Joint Stock were the top three companies having highest ASEAN Corporate Governance Scorecard total score in 2015.

\section{Methodology}

The research is designed to evaluate Corporate Governance mechanism of 60 listed companies in two industries in Vietnam at time 2015, 2017 and 2018 by using the ASEAN balanced scorecard and their relationship with firm performance. There will be 180 observations in total.

\subsection{Sample selection}

Sample size of 60 non-financial companies, in which 30 listed companies are in Food \& Beverage \& Consumer Goods Industry, another 30-listed company belong to Construction and Real Estate Industry in HOSE and HNX Stock Exchange are chosen to undertake the Corporate Governance assessment using ASEAN scorecard method. These are the two biggest industries in Vietnam market with market capitalization estimated to be 861,459.38 and $577,288.97$ billion Vietnam dong respectively (Financial Industry is excluded). Additionally, the information needed for evaluation is taken from three years, which are 2015, 2017 and 2018 so that it will be easier to track the improvement of each company's Corporate Governance practices over the time. Hence, there will be 180 observations in total.

\subsection{ASEAN scorecard for Vietnam Corporate Governance}

According to the report prepared by a group of Association of Southeast Asian Nations Corporate Governance Experts (2016), The ASEAN corporate governance scorecard is a great supporting tool to measure ASEAN corporate governance, which is endorsed by the ASEAN Capital Markets Forum (ACMF).

The ASEAN scorecard was developed based on international benchmarks and framework of the Organization for Economic Co-operation and Development (OECD) Principles of Corporate Governance (2004), the International Corporate Governance Network Corporate Governance Principles and industry-leading practices from ASEAN \& the world. The objective of developing publicly listed companies' governance standards is to give Southeast Asia Nations a greater universal perceptibility towards well-governed listed companies and encourage them to improve their practices to reach their global counterparts' level. Moreover, it also complements other ASEAN Markets Forum initiatives and promotes ASEAN as an asset class (ACMF 2017).

There are two levels of scoring designed for ASEAN scorecard assessment. The calculation based on two scoring dimensions is likely to reflect the actual execution of the substance of good Corporate Governance better.

According to ACMF country report (2015), Level 1 contains descriptors or components that are, fundamentally, characteristics of the laws, regulations, rules and basic expectation of OECD principles. In details, in this level, there are five areas of OECD principle that the scorecard covers:

Part A: Rights of Shareholders

Part B: Equitable Treatment of Shareholders

Part C: Role of Stakeholders

Part D: Disclosure and Transparency

Part E: Responsibilities of the Board

It is essential to note that the attributes included in two levels are not necessarily legally required but those constructed ones are considered as the good components contributing to great Corporate Governance mechanism by international standards.

The ASEAN scorecard, further understanding as CGI, is not survey-based. Thus, it means that the questions are answered from available information, which is already revealed by listed companies. In other words, the method used keeps assessors away from conceivably emotional or subjective answers. The sources of information needed to accomplish the questions in two levels are normally gotten from annual reports, company's charter \& regulation and annual general meeting documents. It is easy to get access to those documents through company website or stock exchange information website such as finance.vietstock.vn, cafeF.vn - the two useful sources of website for listed firms in Vietnam.

There are about 183 questions in ASEAN scorecard, which are divided into 02 level. Each question corresponds to a "Yes" or "No" answer. The maximum value for each question is one and the minimum value is 0 . If answer to the question is "Yes", then the score of question is 1 point. In other hands, if answer to the question is "No", then the value of 0 is attributed to that question. 
Table 1. Weight and maximum score assigned for each part in level 1

\begin{tabular}{|l|l|l|l|}
\hline Level 1 & $\begin{array}{l}\text { Number of } \\
\text { Questions }\end{array}$ & $\begin{array}{l}\text { Weight (as a \% of total } \\
\text { Level 1 score) }\end{array}$ & $\begin{array}{l}\text { Maximum Attainable } \\
\text { Score (points) }\end{array}$ \\
\hline Part A: Rights of Shareholders & 21 & 10 & 10 \\
\hline Part B: Equitable Treatment of Shareholders & 15 & 15 & 15 \\
\hline Part C: Role of Stakeholders & 13 & 10 & 10 \\
\hline Part D: Disclosure and Transparency & 32 & 25 & 25 \\
\hline Part E: Responsibilities of the Board & 65 & 40 & 40 \\
\hline
\end{tabular}

Level 1 comprises of 146 components, which are separated into five sections relating to the OECD standards. A reasonable weight, which is in relation to the total Level 1 score of 100 points, is assigned to each part depending on the relative significance of the category.

Table 2. Maximum score assigned for each part in level 2

\begin{tabular}{|l|l|l|}
\hline Level 2 & Number of Questions & $\begin{array}{l}\text { Maximum Attainable Score } \\
\text { (points) }\end{array}$ \\
\hline Bonus & 12 & 10 \\
\hline Penalty & 25 & 10 \\
\hline
\end{tabular}

Level 2 includes bonus and penalty elements, which is designed with the intention of improving the strength of the ASEAN scorecard in evaluating Corporate Governance of companies in practice. The reason for the bonus questions is to acknowledge organizations that exceed the fundamental in Level 1 by implementing good Corporate Governance practices. In contrast, penalty questions are meant to punish the companies with poor Corporate Governance practices that are not included in Level 1 scored categories, for example, getting sanctions for violating the listing rules. In details, Level 2 comprises of 12 bonus questions and 25 penalty questions and each category is given different total score. In penalty section, the score achieved will be then deducted from the total score gotten from Level 1 and Level 2.

Lastly, the maximum score that can be achieved in total of 02 levels is 110 points and the minimum score is -10 points.

\subsection{Methodology specification}

Firstly, it is necessary to have a summary of all variables used in this paper: The variables are summarized as the following table below:

Table 3. Descriptions of variables and expected effects of independent variables on dependent variables

\begin{tabular}{|c|c|c|c|}
\hline Variables & Description & Measurement & $\begin{array}{l}\text { Expected } \\
\text { sign }\end{array}$ \\
\hline \multicolumn{4}{|l|}{ Dependent variables } \\
\hline TOBINQ & Tobin's Q ratio & $\begin{array}{l}\text { Tobin's } Q=(\text { Market Value of Firm }) /(\text { Book } \\
\text { Value of Firm }) .\end{array}$ & \\
\hline ROA & Return on assets & ROA $=$ Net income/Total Assets & (2) \\
\hline ROE & Return on equity & ROE $=$ Net income/Total Equity & \\
\hline \multicolumn{4}{|l|}{ Independent variables } \\
\hline PA SHAREHOLDERS & & & Positive \\
\hline PB_EQUITABILITY & \multicolumn{2}{|c|}{ Equitable treatments of shareholders } & Positive \\
\hline PC_STAKEHOLDERS & Roles of stakeholders & & Positive \\
\hline PD_DISCLOSURE & \multicolumn{2}{|c|}{ Disclosure and transparency } & Positive \\
\hline PE_BOARD & \multicolumn{2}{|c|}{ Responsibilities of the Board } & Positive \\
\hline TOTAL & \multicolumn{2}{|c|}{ Total governance of 2 levels } & Positive \\
\hline \multicolumn{4}{|l|}{ Control variables } \\
\hline LEVERAGE & Leverage ratio & Ratio of Total debt/total assets & Positive \\
\hline SIZE & Size of the firm & $\log ($ assets $)$ & Positive \\
\hline
\end{tabular}

Next, the study uses OLS to regress the association between Corporate Governance index and firm performance:

$$
\pi_{\text {itk }}=\beta_{1}+\beta_{2} \text { TOTAL }_{\text {it }}+\beta_{3} \text { SIZE }_{i t}+\beta_{4} \text { LEVERAGE }_{\text {it }}+\varepsilon
$$

Reasons to separately test the influence of independent variable TOTAL on the firm performance:

Total score of each company's Corporate Governance is calculated by combining points from all other categories, which include: Part A: Shareholders' rights, Part B: Equitable treatment of shareholders, Part C: Roles of stakeholders, Part D: Disclosure and transparency, Part E: Board duties and responsibilities, Bonus section and Penalty section. It means that the variable TOTAL shares same information with other independent variables (PA_SHAREHOLDERS, PB_EQUITABILITY, PC STAKEHOLDERS, PD DISCLOSURE, PE BOARD). ). Moreover, as stated in descriptive data section after, there exists high correlation (over 0.8 ) between TOTAL and other independent variables. Therefore, in order to avoid the problem of multi-collinearity, it is better to separately 
test the association of TOTAL on firm performance.

Total score of Corporate Governance also includes the score calculated in Bonus and Penalty section. Because of the small weight of score in two sections, it is unnecessary to separate them into two more independent variables. Thus, it will be better if those sections included in TOTAL variable to test the overall significance of Corporate Governance Index on firm performance.

Regression steps will be as follows:

Step 1: Pooled Regression Model is run to examine how 06 regressors (PA_SHAREHOLDERS, PB_EQUITABILITY, PC_STAKEHOLDERS, PD_DISCLOSURE, PE_BOARD, TOTAL) influence the explained variables ROA, ROE, TOBINQ.

Step 2: Error Testing

\section{Results}

4.1 Descriptive statistics

The following Table provide the Descriptive statistic of the Sample

Table 4. Descriptive statistics

\begin{tabular}{|l|l|l|l|l|l|l|l|}
\hline & Mean & Median & Maximum & Minimum & Std. Dev. & Sum & Obs \\
\hline PA_SHAREHOLDERS & 6.19 & 6.67 & 9.52 & 0.00 & 1.84 & 1114.29 & 180 \\
\hline PB_EQUITABILITY & 9.25 & 10 & 12 & 0.00 & 2.334763 & 1665 & 180 \\
\hline PC_STAKEHOLDERS & 3.90 & 3.85 & 8.46 & 0.00 & 1.67 & 702.31 & 180 \\
\hline PD_DISCLOSURE & 16.28 & 17.19 & 20.31 & 0.00 & 3.50 & 2931.25 & 180 \\
\hline PE_BOARD & 10.61 & 10.46 & 30.77 & 0.00 & 3.43 & 1909.54 & 180 \\
\hline TOTAL & 45.54 & 47.67 & 85.26 & 0.00 & 11.00 & 8197.29 & 180 \\
\hline ROA & 5.80 & 4.00 & 81.22 & -12.12 & 9.86 & 1043.19 & 180 \\
\hline ROE & 12.75 & 11.33 & 131.64 & -40.54 & 18.12 & 2294.95 & 180 \\
\hline Q & 1.25 & 0.95 & 9.04 & 0.20 & 1.30 & 211.83 & 169 \\
\hline SIZE & 14.27 & 14.06 & 18.09 & 10.08 & 1.50 & 2568.29 & 180 \\
\hline LEVERAGE & 28.78 & 27.60 & 70.40 & 0.00 & 20.59 & 5179.81 & 180 \\
\hline
\end{tabular}

All data relating to Corporate Governance Index, control variables and firm performance measures of Construction and Food \& Beverage industry in 3 years $(2015,2017$ and 2018) are summarized in the table 10. It can be seen that overall, the total score of Corporate Governance Index using ASEAN balanced scorecard of 60 companies in two industries is about 45 points in average over a maximum attainable score of 110 . Although it is not a high score compared to other countries', the number has demonstrated the determination of Vietnam in improving Corporate Governance practices. According to the information collected by ACMF on 55 listed companies in Vietnam, the average total score of Vietnam Corporate Governance using ASEAN balanced scorecard was only 28.42 in 2012 and went to highest in 2015 with 36.75 points. However, after that, this number has gradually improved to over 45 points.

Similarly, the scores for other categories such as shareholders' rights, equitable treatments of shareholders, disclosure and transparency and board responsibilities have also demonstrated the positive improvement over the years. For example, the closure and transparency of information (PD_DISCLOSURE) have experienced a considerable change from just only 9.30 points in 2012 to 16.28 after that. Additionally, the average point for part C, Stakeholders' roles, during three year-period is almost the same with the score achieved in 2012. It means that companies must reconsider the implementation of those corporate governance practices in this part for achievement of higher score in future.

Besides, the mean figures of ROA, ROE and Tobin's Q are quite good as they are all positive number. Particularly, average Tobin's Q is 1.25, which is higher than 1. This is a good sign to see as the companies generally do generate returns and have high market value.

This section presents the results of six final regression models to demonstrates the quantitative correlation between the dependent variables (ROA, ROE and Tobin's Q) and six independent variables (PA_SHAREHOLDERS, PB_EQUITABILITY, PC_STAKEHOLDERS, PD_DISCLOSURE, PE_BOARD and TOTAL. The data is collected and calculated from two industries including 60 listed companies at time 2015, 2017 and 2018.

After conducting the POOL test, the significant independent variables are defined together with insignificant ones. The models with high $\mathrm{R}$ squared and variables not significant are removed. The equations are developed together and reduced to 6 final equation as follows

\section{Construction industry}

Estimate ROA $=-7.25-1.79 *$ PA_SHAREHOLDER $\quad+\quad 2.44 *$ PB_EQUITABILITY $0.33 *$ PC_STAKEHOLDERS $\quad-\quad 0.61 *$ PD_DISCLOSURE $+0.34 *$ PE_BOARD $\quad+\quad 0.56 *$ SIZE + $0.01 *$ LEVERAGE

Estimated ROE $=-12.85-3.06 *$ PA_SHAREHOLDER $\quad-\quad 0.52 *$ PB_EQUITABILITY 


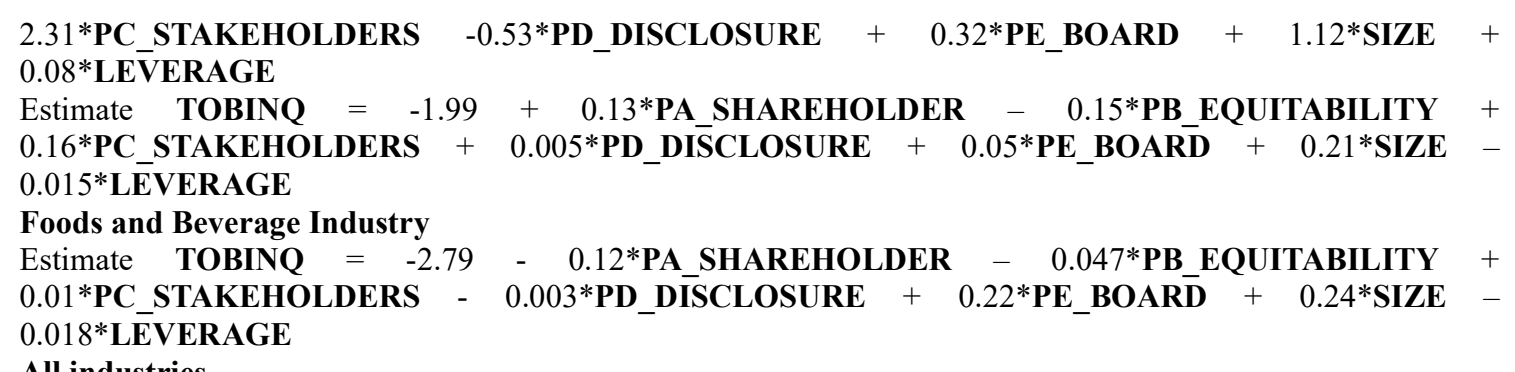

\section{All industries}

Estimated ROE $=-9.88-2.32 *$ PA SHAREHOLDER $+1.80 *$ PB EQUITABILITY + $0.20 *$ PC_STAKEHOLDERS $\quad-\quad 0.19 \%$ PD_DISCLOSURE $\quad+\quad 0.91 *$ PE_BOARD $+\quad 0.87 *$ SIZE + $0.02 *$ LEVERAGE

Estimate TOBINQ $=-2.55+0.01 *$ PA_SHAREHOLDER $-0.09 *$ PB_EQUITABILITY + $0.08 *$ PC_STAKEHOLDERS $-0.02 *$ PD_DISCLOSURE $\quad+\quad 0.18 *$ PE_BOARD $\quad+\quad 0.23 *$ SIZE $0.017 *$ LEVERAGE

These equations for all industries can take example as follow: R-squared $=7.12 \%$ indicates that $7.12 \%$ variation in return on equity can be explained by variation of Rights of shareholders, Equitable treatments of Shareholder, Roles of stakeholders, Disclosure and transparency, Board duties and responsibilities, Size and Leverage. The value of R-squared implies a weak explanation for the fitness of data in the model.

PA_SHAREHOLDERS, PB_EQUITABILITY, PC_STAKEHOLDERS, PD_DISCLOSURE, PE_BOARD are insignificant to ROA and ROE given $90 \%$ confidence level

\section{Conclusion \& Discussion}

5.1 Discussion on the Corporate Governance score of companies in Vietnam using ASEAN balanced scorecard Rights of shareholders

First, average points in three years for the category of "Shareholders' rights" (PA SHAREHOLDERS) of companies in Construction Industry is 6.21 points over the maximum points of 10 for this part. Overall, it means that the companies are doing the protection for shareholders quite well.

Similar to Construction industry, companies in Food \& Beverage industry gain the average point of 6.17 for "Rights of shareholders" category. Specially, there is a company in the industry that achieves an outstanding score for this part, which is Vinamilk. With the nearly perfect scores of 9.5, 8.6 and 9.0 in 2015, 2017 and 2018 respectively, Vinamilk has shown the whole market a model of what the good corporate governance practices for shareholders are.

Equitable treatment of shareholders

The maximum score for equitable treatments of shareholder (PB_EQUITABILITY) in ASEAN scorecard is 15 points, and the average score for this category of 30 companies in Construction industry for three-year time is 9.16 , which is quite a good one.

Expectedly, the average score for equitable treatments of shareholder (PB_EQUITABILITY) in ASEAN scorecard in Food \& Beverage industry is not much different from Construction industry as the two scores are all around 9.3 over 15 points. Reason for the similarity in score is that Food \& Beverage industry are also encountering the same issues with Construction industry.

\section{Roles of stakeholders}

In Construction industry, "Role of stakeholders" category average score is only 3.11 over the maximum attainable score for this part is 10 points. The maximum score of 6.15 points belongs to FLC Faros, which is a comparable low score. Reason for the low score in this part is mainly because Construction companies lack of evidence in demonstrating their responsibilities to society. In details, in 2015, there are 29 companies that did not have the separate section in annual report discussing their efforts on environmental and social issues. In 2017 and 2018, it seemed that Construction companies gradually notice and become more concerned about their responsibilities for community.

Stakeholders' right in Food \& Beverage industry is also not clearly shown by companies so that the mean point for this section is quite low with 4.69 over 10 points. However, this point is still higher than Construction industry about 1 point. The reason for this difference is that Food \& Beverage companies have better performance in showing their concerns toward environment and society. In 2018, there are only four companies that did not have separate section in annual report to discuss their efforts on environmental and social issues as well as promote sustainable development. Similar to the case of Construction industry, almost all Food \& Beverage companies rarely disclose the policy of protecting employees from retaliation when informing unethical behaviors except for Vinamilk. 


\section{Disclosure and transparency}

That the constructed category includes 32 questions and accounts for $25 \%$ of the total score of Corporate Governance has demonstrated its importance of information transparency in Corporate Governance. Both industry gain the average score of about 16 points over 25 in "Transparency and disclosure", which shows the attempt of companies to provide their stakeholders with as much information as possible.

Due to the results of ASEAN balance scorecard, it is observable that there are some certain questions that constantly receive "No" answers. Those parts have somehow indicated the problems in "Disclosure and transparency" that Vietnam is struggling with. In details, firstly, companies do not completely inform shareholders about the name, relationship and value for each related party transactions. There are no information found in 60 companies for this question. Moreover, about 26 Construction companies and 26 beverage companies do not disclose the direct and indirect shareholdings of substantial shareholders and 60 companies do not reveal the direct and indirect shareholdings of senior management. This may partly make investors and shareholders unable to accurately evaluate the value of the business in the present and in the future.

\section{Board duties and responsibilities}

There are 65 questions in this part accounting for $40 \%$ of total level 1 score. The weight of score assigned for this category shows the significance of board toward its company's Corporate Governance.

The mean score for Construction companies in this part is only 10.01 points, which is less than the maximum attainable score about 30 points. Though FLC Faros (2017) achieved highest score among 30 companies with 14 points but it is still unexpectedly low. Higher than the average score of Construction industry about 1 point, Food $\&$ Beverage companies record the mean score for the whole industry with 11.26 points. Surprisingly, Vinamilk has done such an amazing performance when achieving the highest score among companies with 30.77 points in this part.

Generally, companies often lose points to the questions relating to people on the board, audit committee, remuneration committee and nominating committee. As almost company, except for Vinamilk, do not establish different committee for audit, remuneration or nomination, 59 companies cannot give answers to those questions related. Therefore, for each company, 19 questions covering information about 03 committee are constantly marked with 0 point.

5.2 Discussion on relationship between Corporate Governance Index and firm performance

Firstly, in Construction industry, variable "Rights of shareholders" is statistically significant with 10 percent level of significance, displaying a negative effect with ROA. This result implies that when company does not allow shareholders to participate effectively in company's decisions and limit their rights, company's ROA will increase. Surprisingly, this finding is completely contrary to author's prediction when building the model. As in Food \& Beverage industry, there is not enough evidence to conclude the impact of "Shareholders' rights" on any firm performance measures given $90 \%$ confidence level.

Secondly, in Construction industry, variable "Equitable treatments of shareholders" demonstrates its significant impact on ROA, ROE and Tobin's Q with 1\%, 5\% and 10\% level of significance respectively. Moreover, it is found that "Equitable treatments of shareholders" demonstrate its positive impacts on ROA and ROE, which completely coincides with the paper's hypothesis and expectation. Meanwhile, the variable shows a negative correlation with Tobin's Q, which is a market-based performance of the firm. The outcomes implies a opposite relation of Tobin's Q to ROA, ROE, which reflects the difference in public market's perception and reality of what firm is needed to generate returns.

Thirdly, "Transparency and disclosure" surprisingly shows no impact on the performance of companies in both industries", It was expected that the category might show some connection with the firm performance, at least with Tobin's Q since it is a market-based measure. This result is contrary to the results discovered by Anjala \& Shikha 2016 whose research topic was about the influence of Corporate Governance Disclosure Index on 38 nonfinancial companies listed in National Stock Exchange of India for a five-year period from 2008-2012. Moreover, another conclusion might be withdrawn from the research result is that at a highly instable market like Vietnam, where authentication and fake are confusing, it requires higher point of transparency and information disclosure for companies to gain more investors' trust to surrender funds for equity finance, which in turns strengthens the financial performance of the firms.

Fourth, variable "Roles of stakeholders" shows no influence on any measures except for Tobin's Q in Construction industry. It is statistically significant with 10 percent level of significance, displaying a positive effect with Tobin's Q. Furthermore, the finding of "Roles of stakeholders" having no relationship with ROA is also found in research "Analyzing the impact of the Corporate Governance Index on the performance of listed companies VN30 Index" conducted by Dao \& Nguyen (2018). Their Corporate Governance Index is similarly constructed based on OECD principles with 148 questions divided into 05 categories like ASEAN Corporate Governance balanced scorecard: Shareholders' rights, Equitable treatment of Shareholders, Roles of stakeholders, Disclosure and Transparency, Board duties and responsibilities.

Additionally, as can be observed from the result $(\mathrm{P}$-value $=0.00005)$, "Board duties and responsibility" 
demonstrates its positive influence on only Food \& Beverage companies’ Tobin's Q with 1\% level of significance. In contrast, in Construction industry, it is insignificance to companies' ROA, ROE, and Tobin's Q given 90\% confidence level. This finding is unexpectedly contrary to author's expectation as the important role of a board within an organization is inevitable.

Last but not least, although there have been different results of association between Corporate Governance practices and firm performance in both industries, the finding has discovered a similarity between them, which is the positive influence of total Corporate Governance score (TOTAL) on Tobin's Q. Overall the average value of Tobin's Q in Food \& Beverage industry is 1.48 , meaning that majority of firms sill have market value higher than book value. Meanwhile, this figure for Construction industry is just 1.02. With the similar average total scores of 45.7 (Food \& Beverage) and 45.38 (Construction), it can be seen that companies in Food \& Beverage industry generates higher value of Tobin's Q than that of Construction industry. In other words, total Corporate Governance Index affects companies in Food \& Beverage industry more than those in Construction industries. For further implication, since Tobin's Q is valued based on market expectation and sources of public information, it seems that people' perception of transparency in Food \& Beverage industry is much better than Construction one. It can also understand that people value the public information more in Food \& Beverage sector since Food \& Beverage deals directly with people' health.

\subsection{Recommendation}

Overall, Vietnam needs to keep on improving the legal framework related to Corporate Governance practices in public companies in general and listed companies in particular. After the results of Corporate Governance Index using ASEAN balanced scorecard, there are some outstanding points that every lawmaker, business owner, investor need to pay attention to in order to get higher outcomes.

To begin with, it is important to enhance guidelines on corporate responsibilities for stakeholders, especially for communities, society and the environment because stakeholders play significant roles in corporate businesses. The State needs to supplement regulations to guarantee fairness between major shareholders and small shareholders, between domestic shareholders and foreign ones. For instance, the information disclosure should be provided in two languages English and Vietnamese on listed company's website. This will help to ensure the fairness for foreign shareholders and encourage the foreign investment flows at the same time.

Moreover, it is necessary for Vietnam to learn the implementation of good Corporate Governance from other countries in region as they have many similarities with our countries in general. In this case, Thailand will be given as our example. From the reports published by ACMF in 2015 , on the list of top 50 listed companies whose Corporate Governance scores are highest in Southeast Asian region, Thailand companies accounted for 23 spots over 50. In addition, the Institution of Directors was established is such a turning point for Thailand in the battle of improving Corporate Governance quality. They have had great merits in helping to develop professional directorial standards and giving great practice rules for organization chiefs. Learning from the success of Thailand, it is necessary that Vietnam should establish an organization dedicated to Corporate Governance. This organization will help stakeholders such as directors, executives, investors to raise awareness and knowledge about Corporate Governance as well to develop grading criteria based on international standards as well as the actual situation in Vietnam. Annual surveys can be carried out to assess aspects of Corporate Governance practices in Vietnamese listed companies.

In summary, Corporate Governance is a significant issue for all of the nations in period of globalization and integration. Although Vietnam is starting with the initial period of Corporate Governance implementation, Vietnam needs to learn from countries that have been successful in executing Corporate Governance practices in order to have better performance outcomes.

\section{References}

Anjala, K. \& Shikha, S. (2016). Analysis of Board Size and Firm Performance: Evidence from NSE Companies Using Panel Data Approach. Indian Journal of Corporate Governance, 9 (2) 148-172.

Akshita. \& Shernaz, B. (2018). Relationship between Corporate Governance Index and Firm Performance: Indian Evidence. Global Business Review, 19, no. 3, 675-689.

ASEAN Capital Markets Forum, (n.d.). ASEAN Corporate Governance Scorecard.

Asian Development Bank, (2016). ASEAN corporate governance scorecard country report and assessment 2015.

Bart, F., Rogér, O., \& Alireza, T. (2008). The impact of corporate governance on corporate performance: Evidence from Japan. Pacific-Basin Finance Journal, 16, no. 3, 236-251.

D, A, (2018), Quan tri doanh nghiep: Nang cao tinh minh bach, cong khai thong tin. [Online] Available: http://thoibaotaichinhvietnam.vn/pages/kinh-doanh/2018-12-03/quan-tri-doanh-nghiep-nang-cao-tinh-minhbach-cong-khai-thong-tin-65009.aspx.

Dao, B. \& Hoang, G. (2012). Corporate Governance and performance in Vietnamese commercial banks. Journal of Economics \& Development, 14, no. 2, 72-95. 
Dao, B, (2018). Chi so VN30: Phan tich hieu qua hoat dong va quan tri doanh nghiep. Tap chi Kinh te va Du bao, $12-04 / 2018$ (688), 3-6.

Dao, B. \& Nguyen, L. (2018). Phan tich anh huong cua chi so quan tri doanh nghiep len hieu qua hoat dong cua cacs con ty niem yet VN30 Index. Economy and Forecast Review, 21, 13-16.

Eduardo, T. \& Magdalena, L. (2009). Governance in Southeast Asia: Governance in Southeast Asia: Issues and Options.

Ho, L. (2005). Reforming corporate governance in Southeast Asia: Economics, Politics, and Regulations.

Lanfeng, K., Meilan, T. \& Chinshun, W. (2007). Building a Corporate Governance Index from the Perspectives of Ownership and Leadership for Firms in Taiwan. Corporate Governance: An International Review, 15, no. 2, 251-261.

Manmeet \& Madhu, V. (2018). Corporate governance index and firm performance: empirical evidence from Indian banking. Afro-Asian J. of Finance and Accounting, 8, no. 2, 190.

Nguyen, C. (2008). Corporate Governance in Vietnam: Regulations, practices and problems.

OECD. (2003). Corporate Governance in Development The Experiences of Brazil, Chile, India, and South Africa: The Experiences of Brazil, Chile, India, and South Africa, 2. OECD Publishing.

Pham, T. (2016). Research on the Relationship between Corporate Governance and Firm Performance: Empirical Evidence from Companies Listed on the Stock Exchange in Vietnam. International Journal Of Management and Applied Research, 3, no. 4, 172-183.

Shafie, Z., Kamilah, A. \& Khaw, W. (2016). Corporate Governance Practices and Firm Performance: Evidence from Top 100 Public Listed Companies in Malaysia. Procedia Economics and Finance, Volume 35, Pages 287-296.

Vo, D. \& Nguyen, T. (2014). The Impact of Corporate Governance on Firm Performance: Empirical Study in Vietnam. International Journal of Economics and Finance, 6, no. 6.

Wen-Yen. \& Pongpitch, P. (2010). The Impact of Corporate Governance on the Efficiency Performance of the Thai Non-Life Insurance Industry. The Geneva Papers on Risk and Insurance - Issues and Practice, 35, no. $1,28-49$. 